\title{
Breaking down silos: engaging students to help fix the US health care system
}

\author{
This article was published in the following Dove Press journal: \\ Journal of Multidisciplinary Healthcare \\ 16 February 2015 \\ Number of times this article has been viewed
}

\author{
Mathu A Kumarasamy' \\ Fred P Sanfilippo ${ }^{1-3}$ \\ 'Emory-Georgia Tech Healthcare \\ Innovation Program, ${ }^{2}$ Department of \\ Pathology and Laboratory Medicine, \\ School of Medicine, ${ }^{3}$ Department \\ of Health Policy and Management, \\ Rollins School of Public Health, Emory \\ University, Atlanta, GA, USA
}

Problem: The field of health care is becoming a team effort as patient care becomes increasingly complex and multifaceted. Despite the need for multidisciplinary education, there persists a lack of student engagement and collaboration among health care disciplines, which presents a growing concern as students join the workforce.

Approach: In October 2013, the Emory-Georgia Tech Healthcare Innovation Program organized a student driven symposium entitled "US Healthcare: What's Broken and How to Fix It: The Student Perspective". The symposium engaged students from multiple disciplines to work together in addressing problems associated with US health care delivery. The symposium was organized and carried out by a diverse group of student leaders from local institutions who adopted a multidisciplinary approach throughout the planning process.

Outcomes: The innovative planning process leading up to the symposium revealed that many of the student-discipline groups lacked an understanding of one another's role in health care, and that students were interested in learning how to work together to leverage each other's profession. The symposium was widely attended and positively received by students and faculty from the Atlanta metropolitan area, and has since helped to promote interdepartmental collaboration and multidisciplinary education across institutions.

Next steps: The student symposium will become an annual event and incorporate broader discipline representation, as well as a patient perspective. Proposals for additional institutionwide, multidisciplinary educational offerings are being addressed with the help of faculty and health care providers across the network. Accordingly, the implementation of student-driven symposia to engage students and stimulate institution-wide changes may be a beneficial and cost-effective means for academic health centers looking to facilitate multidisciplinary health care education.

Keywords: multidisciplinary health care education, multidisciplinary student engagement, multidisciplinary team-based learning

\section{Problem}

In the era of US health care reform, providers, payers, and patients across the country are being held more accountable to improve the quality, access, and cost of health care. Given the multifactorial nature of health care, it is no surprise that initiatives including accountable-care organizations and patient-centered medical homes are emerging as viable new care models across the country. These new approaches have one resounding goal in common: to bring multiple professions together in teams to provide better patient-centered health care. In fact, more than a decade ago in 2001, the Institute of Medicine (IOM) report Crossing the Quality Chasm: A New Healthcare System for the 21 st Century called for such a multidisciplinary approach to health care. ${ }^{1}$ More recent
Correspondence: Fred P Sanfilippo Emory-Georgia Tech Healthcare Innovation Program, Emory University, Grace Crum Rollins Building - Room 730, 1518 Clifton Road Northeast, Atlanta, GA 30322, USA

Tel +l 4047780234

Email fred.sanfilippo@emory.edu 
reports from the IOM have established guiding principles and values for team-based health care while reiterating the need for health care practitioners to embrace the transition from being soloists to members of an orchestra. ${ }^{2}$ Adding to the urgency is the ongoing transition from a predominantly volume-based health care system to one governed by value. ${ }^{3}$

Multidisciplinary teams have the potential to create value by increasing quality and patient satisfaction while simultaneously decreasing costs. ${ }^{2}$ Additionally, such teams allow individuals with different expertise to complement one another for the holistic care of the patient. One study has estimated that the average primary care physician connects to 266 other physicians when assessing the medical care network of his or her Medicare patients over a span of 1 year. ${ }^{4}$ However, this estimate does not include the interaction with other professionals, including nurses, physician assistants, pharmacists, social workers, dieticians, technicians, administrators, and many other integral team members. Given the diversity and quantity of health care disciplines, it is imperative for all health care professionals to understand the issues afflicting one another for increased transparency and communication.

The problem of ill-equipped health care professional graduates is not local to the US. The international community has also underscored the need for interprofessional collaboration; in fact, the World Health Organization has indicated that interprofessional education is necessary in creating a "collaborative practice-ready health workforce" capable of improving health outcomes. ${ }^{5}$ Similarly, the groundbreaking report Health Professionals for a New Century featured professional and academic leaders from around the globe who beckoned for an end to the "tribalism of professions", while sharing a global vision and framework calling for change and system redesign of professional health care education. ${ }^{6}$

As noted in the IOM report, change begins in the classroom. To help students and future health care workers prepare for this transition, educators and institutions should provide a means for students to learn and actively problem-solve with one another. Eventually, integration of interprofessional collaboration and endorsement of a team mentality into educational programs will increase multidisciplinary competence, thus leading to better patient outcomes as students join the workforce.

The Emory-Georgia Tech Healthcare Innovation Program (HIP) is a multi-institutional network focused on facilitating health services research, education, and service (http://www.hip.emory.edu). As part of its activities, HIP hosts quarterly symposia with prominent guest speakers from around the country on the topic of "US Healthcare: What's Broken and How to Fix It?" In October 2013, HIP organized its first-ever student-driven symposium to feature the multidisciplinary student perspective on the challenges facing the US health care system.

\section{Approach}

"It's about the journey, not the destination": this popular sentiment aptly embodies the planning process behind the student symposium. From the initial formation of the student planning committee to the final symposium presentations, a multidisciplinary mindset was adopted and integrated throughout the entire process.

\section{Student planning committee}

The initial student planning committee was comprised of ten student leaders from the HIP Student Advisory Group, representing different departments, schools, and universities, with each bringing a different discipline, perspective, and context. Many of these students were selected by the program director based on their leadership positions within various student organizations related to their respective disciplines. The different disciplines represented by the planning committee included public health, medicine, nursing, allied health, business, and engineering. Members of the planning committee included students from Emory University, Georgia Institute of Technology, Georgia State University, and Morehouse School of Medicine. The planning committee members were responsible for 1) selecting a student speaker on behalf of their respective discipline, 2) identifying faculty members from their respective disciplines as mentors for the student speakers, 3) organizing meetings with each of their own respective student organizations, and 4) providing multidisciplinary feedback for the student presentations.

\section{Student speakers}

Seven different student disciplines were selected for the symposium: public health, prehealth, medicine, nursing, allied health, business, and engineering. These disciplines were chosen based on their extensive presence across the multiple institutions. The prehealth discipline was designated for an undergraduate student, while all other disciplines were represented by graduate students. The designated planning committee members were asked to select student speakers based on who they thought would best represent their respective discipline, as well as who provided the best response to the question of "Why is a multidisciplinary approach needed in healthcare?" Student speakers representing each 
discipline were selected through various methods, including submission of YouTube videos, written essays, and personal interviews. Upon selection, student speakers were asked to 1) present one health care-related problem associated with their discipline, 2) identify the contributing factors associated with the problem, and 3 ) propose a potential multidisciplinary solution. To assist with their presentations, student speakers were paired with a faculty mentor and provided access to consult the deans of their respective schools. Additionally, student speakers were encouraged to attend the meetings of other student clubs and organizations across the network.

\section{Open-call student roundtable}

To further assist student speakers with their final presentations, weeks prior to the symposium, an open-call student roundtable was held by the planning committee. The roundtable was organized loosely on the concept of speed dating. Seven roundtables were organized, with each table comprised of approximately five students from the same discipline who were handpicked and selected by the respective planning committee member. The student speakers began at their respective "home" tables, and were asked to rotate to another table every half hour until they received input from students across all seven of the disciplines represented.

Prior to the roundtable, planning committee members researched and printed a "startling" fact pertaining to their discipline. These facts were meant to be provocative, and were used to help stimulate conversation during the roundtable discussions. Overall, the roundtable process was both organic and refreshing: it offered students the opportunity to uncover the real issues troubling each of the other disciplines. It also provided a means to better understand the nature and scope of one another's discipline. Most importantly, the roundtable helped cultivate an environment where students were able to candidly voice some of their concerns, opinions, and questions.

Frequent questions brought up at many of the different roundtables included: "What is the role of your discipline in healthcare?" and "What can we do to help make your job easier?" Fittingly, the student roundtable revealed two salient themes: 1) there was a lack of understanding of one another's profession and role in health care delivery, and 2) students were interested in learning how to work together to complement one another's role. Overall, the open-call student roundtable provided the student speakers with valuable feedback and an exposure to diverse viewpoints outside their respective disciplines. As such, the process was able to inform and help the student speakers formulate multidisciplinary solutions for their final presentations.

\section{Outcomes}

The symposium attracted hundreds of students and faculty from the Atlanta metropolitan area, with additional participants joining via webcast. The student presentations addressed multiple topics within the US health care system, including public health awareness, health care-delivery models, nursing scope of practice, the evolving role of allied health, the medical education curriculum, insurance-led quality improvement, and the risk-averse culture of biomedical engineering. All student speakers successfully presented a health care problem associated with their respective discipline and subsequently provided a multidisciplinary framework to address the problem (see Table 1; access to all the student presentations and a video stream of the symposium is available in Figure S1). Throughout the symposium, social media sites, including Twitter and Facebook, were used to help engage students. Following all the presentations, student speakers formed a panel to entertain an interactive questionand-answer session with the audience.

The symposium was unanimously well received, garnering positive reviews from both students and faculty members across multiple institutions. Since its inception, the student symposium has helped cultivate a greater interest by students across disciplines in health care delivery and multidisciplinary collaboration. It has led to the creation of multiple student "mixers" between various graduate school programs and student clubs, as well as new interdepartmental activities. Of note has been the development of a university-wide course at Emory entitled "SICK: Healthcare in the Modern

Table I Student-identified US health care problem and solution for each discipline

\begin{tabular}{|c|c|c|}
\hline Discipline & Problem & Solution \\
\hline $\begin{array}{l}\text { Public } \\
\text { health }\end{array}$ & $\begin{array}{l}\text { The absence of public } \\
\text { health awareness and } \\
\text { collaboration }\end{array}$ & $\begin{array}{l}\text { Development of properly } \\
\text { aligned incentives across } \\
\text { disciplines }\end{array}$ \\
\hline Prehealth & $\begin{array}{l}\text { The dispersed US health } \\
\text { care-delivery model }\end{array}$ & $\begin{array}{l}\text { A vertically integrated health } \\
\text { maintenance organization }\end{array}$ \\
\hline Nursing & $\begin{array}{l}\text { The decline in primary } \\
\text { care access }\end{array}$ & $\begin{array}{l}\text { Increasing mid-level } \\
\text { practitioner scope of practice }\end{array}$ \\
\hline $\begin{array}{l}\text { Allied } \\
\text { health }\end{array}$ & $\begin{array}{l}\text { The increasing provider } \\
\text { shortage }\end{array}$ & $\begin{array}{l}\text { Implementation of } \\
\text { interdisciplinary care teams } \\
\text { and care coordination }\end{array}$ \\
\hline Medicine & $\begin{array}{l}\text { The incomplete medical } \\
\text { education curriculum }\end{array}$ & $\begin{array}{l}\text { Teaching physicians how to } \\
\text { teach to increase patient } \\
\text { activation }\end{array}$ \\
\hline Business & $\begin{array}{l}\text { The absence of nonclinical } \\
\text { quality improvement }\end{array}$ & $\begin{array}{l}\text { A coordinated quality } \\
\text { bonus-payment system }\end{array}$ \\
\hline Engineering & $\begin{array}{l}\text { The risk-averse culture of } \\
\text { medical technology and } \\
\text { innovation }\end{array}$ & $\begin{array}{l}\text { Interdisciplinary refinement } \\
\text { of medical regulation policies }\end{array}$ \\
\hline
\end{tabular}


Era", which was launched in the spring of 2014. The course was developed to provide students with a multidisciplinary and holistic understanding of the challenges facing the US health care system. The course is available to all students of all disciplines, and covers the US health care system from a myriad of different viewpoints through discussion panels and lectures covering topics in medicine, public health, business, law, ethics, policy, and informatics. Lectures are given by a multidisciplinary assortment of prominent university and health care professors and faculty members. Though the course focuses on US health care delivery, modules on international and comparative health systems are also explored. The course culminates with students forming multidisciplinary groups and presenting a capstone project addressing health care-delivery issues (Table S1; for course syllabus, visit https://scholarblogs.emory.edu/sick for additional information regarding the course). The introduction of this course has led the way for additional university-wide coursework, including a course that opened to all students in the fall of 2014 titled "Health Services Research", which aims to provide students with a better understanding of how multidisciplinary research can be used to improve health care cost, quality, and access.

The semiannual Healthcare Innovation Seed Grant Program is also sponsored by HIP to fund multi-investigator, multidisciplinary teams examining health care services and clinical effectiveness. Following the symposium, and for the first time in the 3 years of the program, a proposal was submitted by a group of students to examine the effectiveness of their own multidisciplinary volunteer health care-related programs.

\section{Next steps}

The success of this symposium and the processes that have engaged multiple student disciplines and activities will be extended to become an annual series of events, and will be expanded to include additional perspectives. The patient perspective will be an especially integral and enlightening perspective to include, mirroring the recent emergence of patient and family advisory councils across a majority of health care systems. Indeed, such a perspective can help reinforce the patient's central role in every health care team and the increasingly popular "nothing about me, without me" mentality. ${ }^{7}$

Initiatives similar to the student symposium, though small, can help lay the foundation and trigger a domino effect for multidisciplinary collaboration and education. Health care educators should view the open-call student roundtable as evidence for the need and interest among students for multidisciplinary education. In addition, the student presentations should be a testament to how multidisciplinary collaboration can engage students and help them think "outside the box" to formulate innovative, multidisciplinary solutions to realworld problems.

As a parallel, business schools across the US have long been recognized for their team-based course structure, where students from all branches of business work together on case studies for which they share the same grades. In fact, certain business schools have recently adopted nondisclosure policies in which students' final grades are only disclosed to employers after being offered employment, as a means to reduce internal competition among students and increase collaboration within the classroom. Conversely, the majority of students pursuing fields in health care are often still taught in independent silos, despite being "graded" and assessed on the same common denominator of patient outcomes upon graduation. Consequently, a strong case can be made for health care educators to adopt a similar approach in which students from all branches of health care interact and work together prior to entering the workforce.

Although a multidisciplinary approach to health care starts at the bottom with students as the foundation, the adoption and implementation of such a philosophy starts from the top. Administrators and faculty members of all disciplines should seek to work together to transform the education system for future health care professionals. In addition, they must serve as role models when interacting and collaborating with one another. It is incumbent upon educational institutions to indoctrinate students into a culture of multidisciplinary collaboration. Though there is no quick fix to the US health care system, a cultural transition toward team-based care could certainly be one of the most crucial and enduring solutions for future generations.

\section{Acknowledgments}

The authors wish to thank HIP Program Manager Maryam Carn, the HIP Student Advisory Group, and the student and faculty participants that helped make the symposium a remarkable success. This study was supported in part by PHS grant UL1TR000454 from the Clinical and Translational Science Award Program, National Center for Advancing Translational Sciences, National Institutes of Health, and the Woodruff Fund, Emory University.

\section{Disclosure}

The authors report no conflicts of interest in this work. 


\section{References}

1. Institute of Medicine. Crossing the Quality Chasm: A New Health System for the 21st Century. Washington: National Academies; 2001.

2. Mitchell PH, Wynia MK, Golden R, et al. Core Principles and Values of Effective Team-Based Health Care. Washington: Institute of Medicine; 2012.

3. Porter ME, Teisberg EO. How physicians can change the future of health care. JAMA. 2007;297(10):1103-1111.

4. Pham HH, O'Malley AS, Bach PB, Salontz-Martinez C, Schrag D. Primary care physicians' links to other physicians through Medicare patients: the scope of care coordination. Ann Intern Med. 2009;150(4):236-242.
5. Frenk J, Chen L, Bhutta ZA, et al. Health professionals for a new century: transforming education to strengthen health systems in an interdependent world. Lancet. 2010;376(9756):1923-1958.

6. World Health Organization. Framework for Action on Interprofessional Education and Collaborative Practice. Geneva: WHO; 2015.

7. Wynia MK, Von Kohorn I, Mitchell PH. Challenges at the intersection of team-based and patient-centered health care: insights from an IOM working group. JAMA. 2012;308(13):1327-1328. 


\section{Supplementary materials}

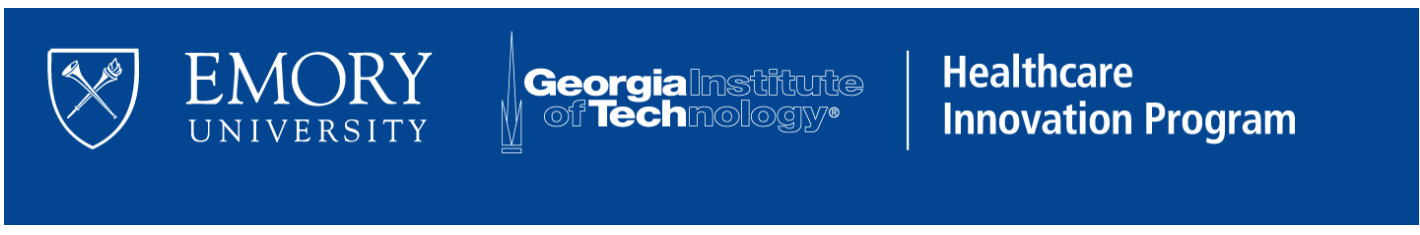

\section{US Healthcare: What's Broken \& How to Fix It \\ Healthcare Innovation Symposium VII \\ The Student Perspective}

October 9, 2013

Emory University

Click here to view video stream

Click below to view presentations from the symposium

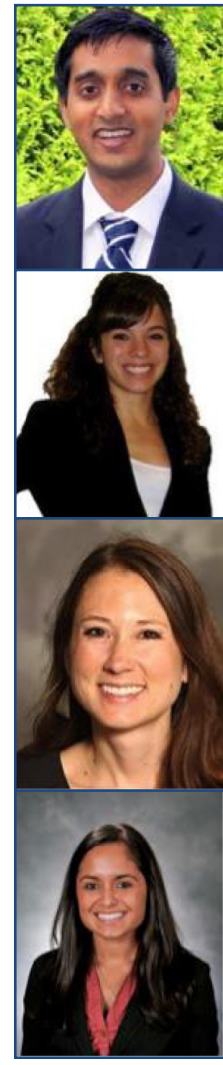

Mathu Kumarasamy

Research Assistant

Office of Quality \& Risk, Emory Healthcare

click here to view slides

College of Arts and Sciences

Emory University

click here to view slides

\section{Mary Micikas}

Nell Hodgson Woodruff School of Nursing

Emory University

click here to view slides

\section{Leena Murthy}

Goizueta Business School

Emory University

click here to view slides

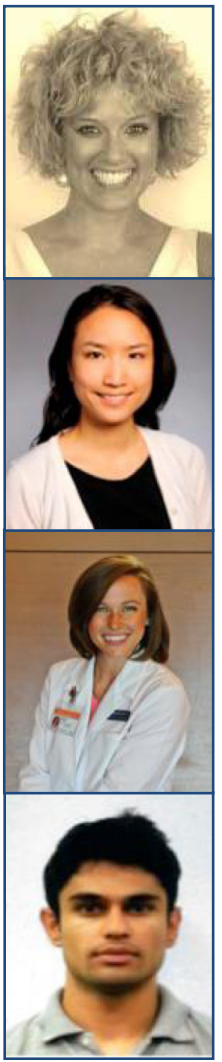

\section{Lindsay Allen}

Health Economics Doctoral Student

Rollins School of Public Health, Emory University

click here to view slides

Kristine Vanijcharoenkarn

School of Medicine

Emory University

click here to view slides

Meredith Brazell

Physician Assistan Program

Emory University School of Medicine

click here to view slides

Figure SI HIP student symposium presentations and video stream.

Abbreviation: HIP, Healthcare Innovation Program. 
Table SI SICK: Healthcare in the modern era, 20I3: course prospectus and materials

\begin{tabular}{|c|c|c|c|c|c|c|c|c|}
\hline \# & Date & Category & Session topic & Lecture topic & School & Dept & Lecturer(s) & Min \\
\hline \multirow[t]{3}{*}{1} & $1 / 16$ & $\begin{array}{l}\text { General/ } \\
\text { medical }\end{array}$ & Introduction & $\begin{array}{l}\text { Introduction to course } \\
\text { schedule and grading }\end{array}$ & Medicine & Neurology & Conveners & 30 \\
\hline & & & & $\begin{array}{l}\text { Doctor's perspective } \\
\text { with cases }\end{array}$ & Medicine & Neurology & $\begin{array}{l}\text { Jaffar Khan } \\
\text { Bob Gaynes }\end{array}$ & 60 \\
\hline & & & & $\begin{array}{l}\text { A social perspective with } \\
\text { cases }\end{array}$ & $\begin{array}{l}\text { Arts and } \\
\text { Sciences }\end{array}$ & Sociology & Jeff Mullis & 60 \\
\hline \multirow[t]{3}{*}{2} & $1 / 23$ & Economics & $\begin{array}{l}\text { Macro- } \\
\text { economics }\end{array}$ & $\begin{array}{l}\text { Overview healthcare } \\
\text { economics US }\end{array}$ & $\begin{array}{l}\text { Arts and } \\
\text { Sciences }\end{array}$ & Economics & Sarah Markowitz & 60 \\
\hline & & & & $\begin{array}{l}\text { Payment models: } \\
\text { current and alternative }\end{array}$ & $\begin{array}{l}\text { Public } \\
\text { Health }\end{array}$ & Health Policy & Steve Culler & 60 \\
\hline & & & & Old and new care models & Medicine & Neurology & Gregory Esper & 60 \\
\hline \multirow[t]{2}{*}{3} & $1 / 30$ & $\begin{array}{l}\text { Context and } \\
\text { comparison }\end{array}$ & & $\begin{array}{l}\text { Historical context for } \\
\text { modern healthcare }\end{array}$ & $\begin{array}{l}\text { Arts and } \\
\text { Sciences }\end{array}$ & History & Elena Conis & 90 \\
\hline & & & & $\begin{array}{l}\text { Comparative health } \\
\text { systems }\end{array}$ & $\begin{array}{l}\text { Public } \\
\text { Health }\end{array}$ & Health Policy & $\begin{array}{l}\text { Richard } \\
\text { Saltman }\end{array}$ & 90 \\
\hline \multirow[t]{3}{*}{4} & $2 / 6$ & Operations I & $\begin{array}{l}\text { Operations } \\
\text { management }\end{array}$ & $\begin{array}{l}\text { Physician/provider } \\
\text { financial challenges }\end{array}$ & Business & Neurology & Diwas KC & 60 \\
\hline & & & $\begin{array}{l}\text { Operations } \\
\text { management }\end{array}$ & $\begin{array}{l}\text { Workforce solutions and } \\
\text { alternatives }\end{array}$ & Nursing & & Dena Gilland & 60 \\
\hline & & & Care models & $\begin{array}{l}\text { Integrated care and } \\
\text { other models }\end{array}$ & Medicine & & Rick Gitomer & 60 \\
\hline \multirow[t]{3}{*}{5} & $2 / 13$ & Operations II & Prevention & $\begin{array}{l}\text { Cost control and } \\
\text { prevention }\end{array}$ & $\begin{array}{l}\text { Public } \\
\text { Health }\end{array}$ & Health Policy & David Howard & 60 \\
\hline & & & Measures & $\begin{array}{l}\text { Outcomes/quality } \\
\text { measures }\end{array}$ & $\begin{array}{l}\text { Public } \\
\text { Health }\end{array}$ & Health Policy & Kimberly Rask & 60 \\
\hline & & & Measures & Benchmarking & $\begin{array}{l}\text { Public } \\
\text { Health }\end{array}$ & Health Policy & Edmund Becker & 60 \\
\hline 6 & $2 / 20$ & & & $\ll<<$ Midterm presentation & s/evaluations >> & $\gg$ & & 90 \\
\hline \multirow[t]{2}{*}{7} & $2 / 27$ & Operations III & Access & $\begin{array}{l}\text { Access to care, } \\
\text { Medicaid }\end{array}$ & $\begin{array}{l}\text { Public } \\
\text { Health }\end{array}$ & Health Policy & Kathleen Adams & 60 \\
\hline & & & $\begin{array}{l}\text { Social } \\
\text { determinants }\end{array}$ & $\begin{array}{l}\text { Vulnerable populations: } \\
\text { Indigence } \\
\text { Pediatrics } \\
\text { Elderly } \\
\text { LGBT }\end{array}$ & Panel & Panel & $\begin{array}{l}\text { Panel: } \\
\text { Leon Haley } \\
\text { Barbara Stoll } \\
\text { Ted Johnson } \\
\text { Schneider }\end{array}$ & $\begin{array}{l}90 \\
20 \\
20 \\
20 \\
20\end{array}$ \\
\hline \multirow[t]{3}{*}{8} & $3 / 6$ & $\begin{array}{l}\text { Healthcare } \\
\text { and politics }\end{array}$ & $\begin{array}{l}\text { Healthcare } \\
\text { policy }\end{array}$ & $\begin{array}{l}\text { Doctors and congress: } \\
\text { politician perspective }\end{array}$ & NA & NA & Tom Price & 60 \\
\hline & & & $\begin{array}{l}\text { Healthcare } \\
\text { policy }\end{array}$ & $\begin{array}{l}\text { Doctors and congress: } \\
\text { lobbyist/liaison }\end{array}$ & Multiple & Multiple & $\begin{array}{l}\text { Matthew Hicks } \\
\text { Andy Lord }\end{array}$ & 60 \\
\hline & & & $\begin{array}{l}\text { Healthcare } \\
\text { reform }\end{array}$ & $\begin{array}{l}\text { Current healthcare } \\
\text { reform and } A C A\end{array}$ & Medicine & Medicine & Maura George & 60 \\
\hline
\end{tabular}




\begin{tabular}{|c|c|c|c|c|c|c|c|c|}
\hline \# & Date & Category & Session topic & Lecture topic & School & Dept & Lecturer(s) & Min \\
\hline \multirow[t]{3}{*}{9} & $3 / 20$ & $\begin{array}{l}\text { Medicine and } \\
\text { the law }\end{array}$ & & $\begin{array}{l}\text { Mass regulations on } \\
\text { healthcare and } A C A\end{array}$ & GSU Law & Law & Fuse Brown & 60 \\
\hline & & & & $\begin{array}{l}\text { Liabilities, regulations } \\
\text { and implications }\end{array}$ & GSU Law & Law & Leslie Wof & 60 \\
\hline & & & & $\begin{array}{l}\text { Patient advocacy and } \\
\text { vulnerable populations }\end{array}$ & Law & Law & Ani Staz & 60 \\
\hline \multirow[t]{2}{*}{10} & $3 / 27$ & $\begin{array}{l}\text { Ethics and } \\
\text { philosophy }\end{array}$ & Ethics & $\begin{array}{l}\text { Principles of medical } \\
\text { ethics overview }\end{array}$ & & & John Banja & 90 \\
\hline & & & & $\begin{array}{l}\text { "Death panels"/end of } \\
\text { life }\end{array}$ & Medicine & Neurology & $\begin{array}{l}\text { Adam Webb; } \\
\text { Tammie Quest }\end{array}$ & 90 \\
\hline \multirow[t]{3}{*}{11} & $4 / 3$ & Scholarship & & $\begin{array}{l}\text { State of health } \\
\text { professional education }\end{array}$ & & & Melissa Faulkner & 60 \\
\hline & & & & $\begin{array}{l}\text { The state of research in } \\
\text { the US }\end{array}$ & & & David Stephens & 60 \\
\hline & & & & $\begin{array}{l}\text { Academic medical } \\
\text { centers }\end{array}$ & Medicine & Neurology & Fred Sanfilippo & 60 \\
\hline \multirow[t]{2}{*}{12} & $4 / 10$ & Technology & $\begin{array}{l}\text { Health and } \\
\text { clinical } \\
\text { informatics }\end{array}$ & $\begin{array}{l}\text { Medical informatics } \\
\text { Specifics TBD }\end{array}$ & $\begin{array}{l}\text { Medicine/ } \\
\text { GA Tech }\end{array}$ & Medicine & Dan Russler & 60 \\
\hline & & & $\begin{array}{l}\text { Health and } \\
\text { clinical } \\
\text { informatics }\end{array}$ & $\begin{array}{l}\text { Medical informatics } \\
\text { Specifics TBD }\end{array}$ & $\begin{array}{l}\text { Medicine/ } \\
\text { GA Tech }\end{array}$ & Medicine & $\begin{array}{l}\text { Mark } \\
\text { Braunstein }\end{array}$ & 60 \\
\hline \multirow[t]{3}{*}{13} & $4 / 17$ & $\begin{array}{l}\text { Special } \\
\text { populations }\end{array}$ & Global health & $\begin{array}{l}\text { International health and } \\
\text { outreach }\end{array}$ & $\begin{array}{l}\text { Public } \\
\text { Health }\end{array}$ & Medicine & Carlos Del Rio & 60 \\
\hline & & & $\begin{array}{l}\text { Emergency } \\
\text { care }\end{array}$ & $\begin{array}{l}\text { Emergency care in the } \\
\text { US }\end{array}$ & Medicine & $\begin{array}{l}\text { Emergency } \\
\text { Medicine }\end{array}$ & Jason Liebzeit & 60 \\
\hline & & & $\begin{array}{l}\text { Vulnerable } \\
\text { populations }\end{array}$ & $\begin{array}{l}\text { Indigent care and other } \\
\text { vulnerable populations }\end{array}$ & Medicine & $\begin{array}{l}\text { Emergency } \\
\text { Medicine }\end{array}$ & $\begin{array}{l}\text { Jada Bussey- } \\
\text { Jones }\end{array}$ & 60 \\
\hline 14 & $4 / 24$ & & & $\ll<$ Final presentatio & $\gg$ & & & \\
\hline
\end{tabular}

Abbreviations: ACA, Affordable Care Act; Dept, department; GA, Georgia; GSU, Georgia State University; LGBT, lesbian, gay, bisexual, and transgender; Min, minutes; NA, not applicable; TBD, to be determined.

\section{Publish your work in this journal}

The Journal of Multidisciplinary Healthcare is an international, peerreviewed open-access journal that aims to represent and publish research in healthcare areas delivered by practitioners of different disciplines. This includes studies and reviews conducted by multidisciplinary teams as well as research which evaluates the results or conduct of such teams or healthcare processes in general. The journal covers a wide range of areas and welcomes submissions from practitioners at all levels, from all over the world. The manuscript management system is completely online and includes a very quick and fair peer-review system. Visit http://www.dovepress.com/testimonials.php to read real quotes from published authors. 